\title{
The effect of jugular or abomasal infusion of amino acids on milk yield in lactating cows fed a protein deficient $\operatorname{diet}^{\dagger}$
}

\author{
M. Carole THIVIERGE ${ }^{\mathrm{a}}$, Jean F. BERNIER ${ }^{\mathrm{a}}$, Pascal DUbReuil ${ }^{\mathrm{b}}$, \\ Hélène LAPIERRE ${ }^{\mathrm{c} *}$
}

\author{
${ }^{a}$ Département des Sciences Animales, Université Laval, Sainte-Foy, QC, Canada, G1K 7P4 \\ b Faculté de Médecine Vétérinaire, Université de Montréal, St-Hyacinthe, QC, Canada, J2S 7C6 \\ ${ }^{\mathrm{c}}$ Dairy and Swine R \& D Centre, Agriculture and Agri-Food Canada, \\ Lennoxville, QC, Canada, J1M $1 \mathrm{Z3}$
}

(Received 30 July 2001; accepted 10 December 2001)

\begin{abstract}
The influence of first-pass splanchnic metabolism was investigated by comparing the response of 5 lactating cows to an infusion of an amino acid mixture into the abomasum or a jugular vein over $5 \mathrm{~d}$ according to a complete block design. The basal diet and the amino acid infusion provided $71 \%$ and $14 \%$ of crude protein requirements, respectively. The jugular infusion increased $(P=0.01)$ milk yield by $0.80 \mathrm{~kg}$ in comparison to the abomasal infusion, but milk protein yield was not altered. The jugular infusion tended to increase $(P=0.06)$ the arterial concentration of total essential amino acids by $11 \%$ relatively to the abomasal infusion. Mammary plasma flow and net fluxes of amino acids and glucose were not affected by the infusion sites. Variations in essential amino acid concentrations suggest that splanchnic metabolism alters peripheral delivery of amino acids but the recirculation of amino acids within the animal decreased the impact of the first-pass splanchnic metabolism on lactational performances.
\end{abstract}

amino acid / cow / infusion / milk yield / protein

Résumé - Effet d'une perfusion jugulaire ou abomasale d'acides aminés sur la production laitière de vaches en lactation alimentées avec une ration déficiente en protéine. L'influence du premier passage des acides aminés dans le tissu splanchnique a été étudiée en comparant la réponse de 5 vaches laitières à des perfusions abomasale ou jugulaire administrées durant $5 \mathrm{j}$ selon un dispositif en blocs complets. La ration de base et la perfusion d'acides aminés fournissaient $71 \%$ et $14 \%$ des besoins en protéine brute, respectivement. La perfusion jugulaire a augmenté $(P=0,01)$ la

\footnotetext{
${ }^{\dagger}$ Lennoxville Research Centre contribution number 742.

* Correspondence and reprints

E-mail: lapierreh@em.agr.ca
} 
production laitière de $0,80 \mathrm{~kg}$ en comparaison à la perfusion abomasale, mais la sécrétion des protéines dans le lait n'a pas été modifiée. La perfusion jugulaire tendait à augmenter $(P=0,06)$ la concentration artérielle des acides aminés essentiels totaux de $11 \%$ relativement à la perfusion abomasale. Le débit plasmatique mammaire et les flux nets des acides aminés et du glucose n'ont pas été affectés par les sites de perfusion. La variation de la concentration artérielle des acides aminés essentiels suggère que le métabolisme splanchnique modifie l'approvisionnement périphérique en acides aminés, cependant, la recirculation des acides aminés a diminué l'impact du premier passage dans le tissu splanchnique sur les performances laitières.

\section{acide aminé / vache / perfusion / production laitière / protéine}

\section{INTRODUCTION}

The liver plays a key role in the maintenance of nitrogen homeostasis through the regulation of urea synthesis and delivery of amino acids to peripheral tissues [31]. This regulation was demonstrated by the increased hepatic removal of histidine, methionine, phenylalanine representing 50 to $87 \%$ of their increased portal absorption during the mesenteric infusion of a mixture of amino acids in late gestation dry dairy cows [48]. For these amino acids, their postsplanchnic supply matches closely their milk output in lactating cows [30] and their ratio of milk output to mammary uptake is close to unity [36]. Consequently, by-passing the liver when infusing amino acids could enhance mammary gland metabolism and milk protein synthesis.

Comparison of results from different experiments appears to support this hypothesis. Jugular infusions of essential amino acids resulted in an average daily increase of $2.9 \mathrm{~g}$ protein $\cdot \mathrm{kg}^{-1}$ milk and $104 \mathrm{~g}$ protein secreted [34, 37, 39]. Abomasal or duodenal infusions of essential amino acids resulted in daily increments of $1.4 \mathrm{~g}$ protein $\cdot \mathrm{kg}^{-1}$ milk and $60 \mathrm{~g}$ milk protein secreted $[1,15]$.

However, the impact of hepatic removal of amino acids, which appeared very high relative to the portal absorption, appears more limited when the hepatic extraction is calculated relative to total inflow. For example, hepatic removal of methionine and phenylalanine averaged, respectively, 35.7 and $44.5 \%$ of portal absorption, but only 7.8 and $9.3 \%$ of total hepatic inflow [4]. The consideration of both, the amino acids absorbed and their consecutive mix-up with the animal pool, which represents a bulk amino acid pool within the animal, could moderate the impact of their first-pass metabolism on their arterial concentration and their following utilization by the udder.

The present experiment was therefore carried out to determine if the first-pass splanchnic metabolism of amino acids would affect their peripheral supply and subsequently, milk protein secretion.

\section{MATERIALS AND METHODS}

\subsection{Animals and management}

Six cows, three in their 1st and three in their 2nd lactation, were used. First and second lactation cows were chosen to avoid backflux of non-mammary blood into the mammary vein that occurs in cows in their 3rd or higher lactation [44]. Cows were, on average, at 84 days in milk (SEM 19) at the start of the experiment. They were housed individually in tie stalls and milked twice daily at $8 \mathrm{~h} 00$ and $16 \mathrm{~h} 00$. A total mixed ration was fed in eight equal meals daily by mean of automated feeders to achieve a nutritional steady state. The amount of feed offered was adjusted individually to $95 \%$ of pre-experimental ad libitum intake to ensure constant feed intake. 


\subsection{Protein deficient diet and amino acid solution}

The basal diet consisted of a total mixed ration composed, on a dry matter basis, of $30.6 \%$ of grass silage, $30.6 \%$ of corn silage, $36.6 \%$ of barley, $0.42 \%$ of soybean meal, and $1.78 \%$ of mineral and vitamin mix. Dry matter content of silages was determined once a week to maintain a constant ratio of ingredients on a dry matter basis. The basal diet was initially formulated to meet 70 and $96 \%$ of daily crude protein and energy requirements [40]. However, using average feed analyses and animal characteristics after the experiment showed that the basal diet provided rather 71 and $90 \%$ of daily crude protein and net energy of lactation $\left(\mathrm{NE}_{\mathrm{L}}\right)$ requirements (Tab. I, [40]).

The amino acid solution infused contained fifteen L-amino acids (Degussa Hüls, Ham, France) with an overall composition similar to the profile of microbial protein (Tab. II, [2, 13, 14, 16, 27, 35]). The infusate supplied the equivalent of $420 \mathrm{~g}$ of crude protein and $1.15 \mathrm{Mcal}$ of $\mathrm{NE}_{\mathrm{L}}$ daily. These represented 14 and $4 \%$ of daily crude protein and $\mathrm{NE}_{\mathrm{L}}$ requirements [40], which were formulated to provide, in combination with the diet, $100 \% \mathrm{NE}_{\mathrm{L}}$ and less than the recommended NRC [40] protein requirements. This protein deficiency was to allow any responses to be differentiated between the two infusion sites, as the amino acids infused into a jugular vein were assumed to provide more amino acids directly to the mammary gland than the abomasal infusion, avoiding the first-pass extraction by the splanchnic tissues. The nutritional equilibrium of cows during the infusion was finally 85 and $94 \%$ of crude protein and $\mathrm{NE}_{\mathrm{L}}$ requirements [40]. The mixture of amino acids did not include asparagine, aspartate, cystein, glutamine, and tyrosine given solubility and stability problems. Mixed amino acids were dissolved in $3.975 \mathrm{~L}$ of sterile water at $60-70{ }^{\circ} \mathrm{C}$ and the $\mathrm{pH}$ adjusted to 7.40 using monobasic sodium phosphate (Sigma-Aldrich Canada Ltd, Oakville, ON). Osmolarity was adjusted to $300 \mathrm{mOsmol} \cdot \mathrm{L}^{-1}(150 \mathrm{mM})$ using sodium chloride. The solution was sterilized through vacuum filters, $0.2 \mu \mathrm{m}$

Table I. Ingredients and chemical analyses of the basal protein deficient total mixed ration meeting $71 \%$ of crude protein $(\mathrm{CP})$ requirements.

\begin{tabular}{lc}
\hline Component & DM basis $(\%)$ \\
\hline Grass silage $^{1}$ & 30.6 \\
Corn silage $^{2}$ & 30.6 \\
Ground barley & 36.6 \\
Soybean meal 48\% & 0.42 \\
Mineral and vitamin mix $^{3}$ & 1.78 \\
$\mathrm{CP}(\%)$ & 13.1 \\
$\mathrm{RDP}^{4}(\%)$ & 73.1 \\
$\mathrm{RUP}^{4}(\%)$ & 26.9 \\
ADF $(\%)$ & 24.3 \\
NDF $(\%)$ & 40.8 \\
\hline
\end{tabular}

${ }^{1}$ Chemical composition of grass silage on DM basis: $15.2 \% \mathrm{CP}, 36.4 \% \mathrm{ADF}$, and $58.9 \% \mathrm{NDF}$.

${ }^{2}$ Chemical composition of corn silage on DM basis: $9.1 \% \mathrm{CP}, 31.3 \% \mathrm{ADF}$, and $48.0 \% \mathrm{NDF}$.

${ }^{3}$ Composition of the mineral and vitamin mix: $15 \% \mathrm{Ca} ; 5 \% \mathrm{P} ; 10.8 \% \mathrm{Na} ; 5 \% \mathrm{Mg} ; 0.19 \% \mathrm{~K} ; 0.12 \% \mathrm{~S} ; 0.021 \mathrm{~g} \cdot \mathrm{kg}^{-1} \mathrm{Se}$; $1.09 \mathrm{~g} \cdot \mathrm{kg}^{-1} \mathrm{Cu} ; 3.63 \mathrm{~g} \cdot \mathrm{kg}^{-1} \mathrm{Mn} ; 5.45 \mathrm{~g} \cdot \mathrm{kg}^{-1} \mathrm{Zn} ; 2.9 \mathrm{~g} \cdot \mathrm{kg}^{-1} \mathrm{Fe} ; 0.04 \mathrm{~g} \cdot \mathrm{kg}^{-1} \mathrm{Co} ; 0.109 \mathrm{~g} \cdot \mathrm{kg}^{-1} \mathrm{I} ; 490000 \mathrm{IU} \cdot \mathrm{kg}^{-1}$ vit. A; $165000 \mathrm{IU} \cdot \mathrm{kg}^{-1}$ vit. D; $1100 \mathrm{IU} \cdot \mathrm{kg}^{-1}$ vit E; $0.650 \mathrm{~g} \cdot \mathrm{kg}^{-1} \mathrm{~F}$.

${ }^{4} \mathrm{RDP}$ and RUP means rumen degradable and undegradable protein, respectively. 
Table II. Composition of the L-amino acid (AA) mixture infused into the abomasum or jugular vein.

\begin{tabular}{llrc}
\hline & & $\mathrm{g} \cdot \mathrm{d}^{-1}$ & $(\%)$ \\
\hline Essential AA & Arginine & 24.4 & 5.8 \\
& Histidine & 11.0 & 2.6 \\
& Isoleucine & 29.6 & 7.0 \\
& Leucine & 40.5 & 9.6 \\
& Lysine monohydrate & 44.4 & 9.4 \\
& Methionine & 11.6 & 2.8 \\
& Phenylalanine & 24.1 & 5.7 \\
& Threonine & 29.9 & 7.1 \\
& Tryptophan & 6.7 & 1.6 \\
& Valine & 29.0 & 6.9 \\
& Total essential & 251.2 & 59 \\
Nonessential AA & & \\
& Alanine & 35.3 & 8.4 \\
& Glutamate & 64.7 & 15.4 \\
& Glycine & 30.3 & 7.2 \\
& Proline & 18.6 & 4.4 \\
& Serine & 24.7 & 5.9 \\
& Total nonessential & 173.6 & 41 \\
\hline
\end{tabular}

pore size (VacuCap ${ }^{\circledR} 60$, Gelman Sciences, Ann Arbor, MI), into an amber bottle stored at $4{ }^{\circ} \mathrm{C}$ until infusion. Each solution was prepared one or two days before the infusion day.

\subsection{Surgeries, experimental plan and procedures}

\subsubsection{Surgeries}

Surgeries were conducted at least $30 \mathrm{~d}$ before the experiment began and were approved by the Research Centre Institutional Animal Care Committee. Animals were treated according to the Canadian Council on Animal Care [11] guidelines. Under general anesthesia, chronic catheters were implanted in the abomasum, the mesenteric vein, and a mesenteric artery. Catheters used were made of Tygon ${ }^{\circledR}$ (Norton Performance Plastics, Akron, Ohio) and $17 \mathrm{G}$ catheters were placed in an artery and a mesenteric vein while a $19 \mathrm{G}$ catheter was inserted into the abomasum. Catheters were exteriorized on the back of the animal and covered with a sterile gauze pouch. A carotid artery was elevated subcutaneously to provide an alternative source of blood would the arterial catheter fail. A sampling catheter $(19 \mathrm{G})$ was placed in the lateral branch of the cranial mammary vein $24 \mathrm{~h}$ before blood sampling.

\subsubsection{Experimental plan}

This experiment was designed initially to quantify the impact of the intestine, the liver and total splanchnic tissues on mammary gland metabolism. Infusions were planned into the abomasum, a mesenteric vein, and a jugular vein for pre-intestine, post-intestine/pre-liver, and post-liver supply of the amino acid mixture, respectively. Treatments were allocated according to a replicated $3 \times 3$ Latin square design, one 
square for 1st lactation cows and one square for 2nd lactation cows. Each experimental period lasted $7 \mathrm{~d}$, where the last $5 \mathrm{~d}$ were used for the continuous infusion of the amino acid mixture. An infusion period of 5-d was considered adequate because the milk protein response of the mammary gland occurs within $24 \mathrm{~h}$ [39].

Unfortunately, during the mesenteric infusion of amino acids, several cows appeared disturbed and stopped eating. This treatment, therefore, was discontinued. Also, the abomasal catheter of a second lactation cow failed and this cow was removed from the experiment. The experimental design was therefore reorganized as a complete block design involving five cows, three in their first and two in their second lactation representing five blocks with two treatments, abomasal and jugular infusions. These two treatments were repeated on two of the five cows because they did not fully recover their dry matter intake in the period following infusion into the mesenteric vein.

\subsubsection{Experimental procedures}

Cows were adapted to their basal diet for 3 weeks prior to the experiment. Throughout the study, feed intake and milk yield were recorded daily. Orts were sampled and pooled in proportion to daily amounts. Milk was sampled on the last $3 \mathrm{~d}$ of the pre-experimental period, where cows received $71 \%$ of their crude protein requirements, and during each infusion period where they received $85 \%$ of crude protein requirements. A total collection of urine was performed over the last $3 \mathrm{~d}$ of each infusion period. Approximately $150 \mathrm{~mL}$ of concentrated $\mathrm{H}_{2} \mathrm{SO}_{4}$ was needed to maintain urine $\mathrm{pH}$ below 3 for $20 \mathrm{~L}$ of urine. Samples of milk and urine were kept frozen at $-20{ }^{\circ} \mathrm{C}$ until analyses. Body temperature was taken twice daily during the experiment; no antibiotic was added to the intravenous infusion solution.

On the morning of the 5th infusion day, after the morning milking, the residual milk was removed using an intravenous 10 IU injection of oxytocin (Ocytocin Injection U.S.P., Sanofi Santé Animale Inc., Victoriaville, QC, Canada). Blood was then sampled simultaneously from the artery and the mammary vein, beginning $30 \mathrm{~min}$ after the morning milking and performed every 30 min over a 8 -h period. Immediately after the last blood sample, the evening milking was performed and completed with an intravenous $10 \mathrm{IU}$ injection of oxytocin to remove residual milk. The arterial concentrations of amino acids while cows were receiving the protein deficient basal diet were also determined on the last day of the pre-experimental period using procedures similar to those described above. Blood samples were kept on ice until further processing.

\subsection{Chemical analyses}

\subsubsection{Milk, feed and urine}

Milk was analyzed for $\mathrm{N}$ (crude protein $=$ $\mathrm{N} \times 6.38)$ using a Leco analyzer (FP-428 N; Leco Corp., St. Joseph, MI). Freeze-dried samples of silages, concentrates and orts were analyzed for $\mathrm{N}$ using Kjeldahl (crude protein $=\mathrm{N} \times 6.25)$ and ash according to standard procedures [3]. Feed fiber fractions (NDF and ADF) of silages were analyzed according to Van Soest and Robertson [46]. Acidified samples of urine were analyzed individually for total $\mathrm{N}$ using the micro-Kjeldahl method (Tecator 1030, Höganäs, Sweden). Urea-N was analysed using an automatic analyzer (Technicon Autoanalyser II, Technicon Instruments Corporation, Tarrytown, NY), as described previously [23].

\subsubsection{Blood samples}

Immediately after sampling, packed cell volume was determined using the microhematocrit method [43]. Plasma was obtained from centrifugation of whole blood at $3000 \mathrm{rpm}$ for $15 \mathrm{~min}$ at $4{ }^{\circ} \mathrm{C}$. For each sample, separate portions of plasma were frozen $\left(-20{ }^{\circ} \mathrm{C}\right)$ for subsequent amino acid, glucose, and insulin analyses. 
Before analyses, four consecutive plasma samples were pooled by volume to yield four 2-h pooled samples for the various chemical analyses. For amino acid concentration, $200 \mu \mathrm{L}$ of norleucine $(0.5 \mathrm{M})$ were added to $1 \mathrm{~mL}$ of plasma and the mixture was deproteinized with $25 \mathrm{mg}$ sulfosalisylic acid. The supernatants were analyzed by ion-exchange chromatography with ninhydrin as the colorimetric reagent (LKB 4400 Amino Acid Analyser, LKB Biochrom Ltd, Cambridge, UK). Plasma glucose was determined using an enzymatic assay (Boehringer Mannheim kit \#166391, Dorval, QC, Canada). Plasma insulin concentration was determined using double antibody RIA as described by Lapierre et al. [28]. Inter and intra-assay coefficients of variation for insulin were 6.6 and $13.2 \%$, respectively.

\subsection{Calculations}

Mammary extraction rate for a given nutrient was calculated as the plasma arteriovenous concentration difference (AV) across the udder, divided by the arterial concentration. Mammary plasma flow (MPF) was estimated according to the Fick principle using paired milk and plasma samples. A correction factor of $3.5 \%$ for blood-borne proteins secreted directly in milk was applied $(\mathrm{MPF}=(($ milk Phe $+\mathrm{Tyr}) \times 0.965) /$ (AV Phe + Tyr) [12]). Average literature values for milk protein concentrations of phenylalanine and tyrosine were used [24].

Mammary plasma net fluxes of nutrients were calculated by multiplying the arteriovenous concentration difference by the plasma flow. Mammary amino acid uptake to output ratios were calculated as the plasma net flux of a given amino acid divided by the amount secreted in milk for the same period.

\subsection{Statistical analyses}

The mean treatment effects of the abomasal and jugular infusion site for the various parameters were analyzed according to a complete block design using GLM procedures of SAS [41]. Individual cows were considered as blocks and treatment effects were included in the model. Means and pooled standard error of the means are presented in tables. Probability $P \leq 0.05$ was considered significant and $0.05<P \leq 0.10$ was considered as a trend unless otherwise noted.

Pre-study milk and crude protein yields, when cows were offered $100 \%$ of their crude protein requirements, were subtracted from the values from the pre-experimental period where $71 \%$ of their crude protein requirements were met. This result was tested for the difference from zero using the Student's $t$-test according to SAS [41]. A similar statistical test was performed to compare the lactational performances resulting from the jugular and abomasal infusions with those from the pre-experimental period $(71 \%$ crude protein). Arterial amino acid concentrations during the pre-experimental period (71\% crude protein requirements) were subtracted from the values observed during both amino acid infusions and the difference from zero was tested similarly using the Student's $t$-test.

\section{RESULTS AND DISCUSSION}

\subsection{Animal performances}

Dry matter and crude protein intake remained similar throughout the experiment (Tab. III). The jugular infusion of amino acids increased $(P=0.01)$ milk yield by $0.8 \mathrm{~kg} \cdot \mathrm{d}^{-1}$ in comparison to the abomasal infusion. However, the jugular infusion did not increase milk protein content or yield in comparison with the abomasal infusion. This contrasts with observations made from the comparison of separate experiments, which used cows at similar lactation status and similar protein deficient diets. These results suggest that milk protein yield in response to additional essential amino acid supply would be greater with jugular than 
Table III. Milk and urine composition and yield in cows receiving an abomasal (Abo) or jugular (Jug) infusion of fifteen amino acids ${ }^{1}$.

\begin{tabular}{lcccc}
\hline & Abo & Jug & SEM & Site effect $^{2}$ \\
\hline DMI $(\mathrm{kg})$ & 16.5 & 16.3 & 0.2 & $\mathrm{~ns}$ \\
CP intake $(\mathrm{kg})$ & 2.0 & 2.0 & 0.04 & $\mathrm{~ns}$ \\
& & & & \\
Milk $^{3}$ & & & & \\
$\quad$ Yield $\left(\mathrm{kg} \cdot \mathrm{d}^{-1}\right)$ & 25.1 & 25.9 & 0.1 & 0.01 \\
Crude protein $\left(\mathrm{g} \cdot \mathrm{kg}^{-1}\right)$ & 34.9 & 34.5 & 0.3 & $\mathrm{~ns}$ \\
Crude protein yield $\left(\mathrm{g} \cdot \mathrm{d}^{-1}\right)$ & 863.0 & 888.6 & 16.9 & $\mathrm{~ns}$ \\
& & & & \\
Urine & & & & \\
$\quad$ Yield $\left(\mathrm{kg} \cdot \mathrm{d}^{-1}\right)$ & 13.5 & 11.9 & 0.4 & 0.04 \\
Total $\mathrm{N}\left(\mathrm{g} \cdot \mathrm{kg}^{-1}\right)$ & 7.65 & 8.37 & 0.46 & $\mathrm{~ns}$ \\
$\quad$ N excretion $\left(\mathrm{g} \cdot \mathrm{d}^{-1}\right)$ & 103.9 & 97.6 & 4.7 & $\mathrm{~ns}$ \\
$\quad$ Urea-N $\left(\mathrm{g} \cdot \mathrm{kg}^{-1}\right)$ & 3.92 & 4.31 & 4.62 & $\mathrm{~ns}$ \\
Urea-N excretion $\left(\mathrm{g} \cdot \mathrm{d}^{-1}\right)$ & 53.5 & 49.4 & 4.2 & $\mathrm{~ns}$ \\
\hline
\end{tabular}

${ }^{1}$ Least square means with pooled standard error of the mean (SEM) are presented.

${ }^{2}$ Probability of infusion site effect (Abo vs. Jug); ns = non significant, $P>0.10$.

${ }^{3}$ Daily milk and protein yield in the pre-experimental period when feeding $71 \%$ of protein requirements were $24.8 \mathrm{~kg}$ and $938 \mathrm{~g}$, respectively.

abomasal infusions. Briefly, the jugular infusions of 208 to $312 \mathrm{~g}$ of essential amino acids in cows fed 11.7 to $14.5 \%$ crude protein diet at 11 to 30 weeks post-partum resulted in an average increase of $2.9 \mathrm{~g}$ protein $\cdot \mathrm{kg}^{-1}$ milk and $104 \mathrm{~g}$ protein secreted in milk per day [34, 37, 39]. Whereas, with abomasal or either duodenal infusions of 208 to $468 \mathrm{~g}$ of essential amino acids in cows fed 14.0 to $14.4 \%$ crude protein diet at 11 to 28 weeks post-partum, milk protein content and yield increased by $1.4 \mathrm{~g} \cdot \mathrm{kg}^{-1}$ milk and $60 \mathrm{~g}$ protein daily, respectively [1, 15]. Complementary to these experiments, the infusion of essential amino acids into the abomasum or a mesenteric vein resulted in similar milk protein contents and yields [1]. Such observations enabled therefore the suggestion that the liver was the tissue controlling amino acid peripheral appearance and would limit their subsequent use for milk protein synthesis. The current results, however, suggest, that infusing essential and non essential amino acids post-splanchnic in cows having a protein deficiency results in a modification in milk yield without any alteration in milk protein concentration.

The protein restriction induced by the transition from 100 to $71 \%$ crude protein requirements during the pre-experimental period tended to decrease the daily milk and crude protein yields from 26.8 to $24.8 \mathrm{~kg}$ (SEM 1.20; $P=0.07$ ) and from 894.2 to $838.9 \mathrm{~g}$ (SEM 38.0; $P=0.09$ ), respectively. This indicates that the protein deficient diet did cause a limitation on lactation performances. However, when milk productions resulting from both infusions are compared with the pre-experimental period, milk yield remained similar to the pre-experimental production $(24.8 \mathrm{~kg})$ when the amino acids were infused into the abomasum $(25.1 \mathrm{~kg})$ but the post-splanchnic delivery of amino acids numerically increased $(P=0.16)$ milk yield by $1.1 \mathrm{~kg}$ (Tab. III). Therefore, the low responsiveness of the cows to the amino acid infusions does not totally rule out the impact of the first pass across the liver. 


\subsection{Urinary $\mathbf{N}$}

Jugular supply of amino acids decreased $(P=0.04)$ the daily urine volume by $12 \%$ compared with the abomasal infusion (Tab. III). This was offset by a rise $(P>0.10)$ in urinary nitrogen content, such that similar urinary $\mathrm{N}$ excretions were maintained for both sites of infusion. The removal of $\mathrm{N}$ components not directly involved in amino acid catabolism from the urinary $\mathrm{N}$ pool, by focusing on urea-N excretion, provides a similar conclusion (Tab. III). It is known that cows underfed in protein excrete less urinary $\mathrm{N}[17,49]$ given both reduced absorption of ammonia and decreased hepatic catabolism of amino acids [29]. In the present study, the protein deficiency occurring with ingested protein plus infusions of amino acids was planed to ensure that any difference between infusion sites would not be masked by an excess of protein, creating a maximal response situation. However, the similar urinary $\mathrm{N}$ and urea- $\mathrm{N}$ excretion for both infusion sites suggests that an adaptation of cows to a protein deficiency may have reduced the impact of the liver catabolism of amino acids infused into the abomasum. Thereby, the difference in urinary $\mathrm{N}$ as well as urea- $\mathrm{N}$ excretion between the abomasal and the jugular infusions of amino acids may have been reduced.

\subsection{Amino acid arterial concentrations}

The arterial concentrations of methionine and histidine during the pre-experimental period were 12 and $19 \mu \mathrm{M}$, respectively (Tab. IV). In well-fed lactating cows, concentrations ranged from 16 to $20 \mu \mathrm{M}$ for methionine and from 42 to $57 \mu \mathrm{M}$ for histidine $[21,33,38]$. Thus, the low protein diet induced methionine and histidine concentrations that were 30 and $60 \%$ lower than expected in well-fed animals. This again suggests that these amino acids were in insufficient supply relative to requirements based on the concept that low free amino acid concentrations in arterial plasma reflect an imbalance between dietary and endogenous input versus tissue removal [7]. When methionine was supplied with both infusions, only a small increment in arterial concentration occurred compared with the preexperimental period, suggesting that its requirement was still not met with infusions. In contrast, histidine arterial concentrations increased $(P<0.05)$ from 19.0 to $35.9 \mu \mathrm{M}$ during the infusions of amino acids. These observations suggest that methionine was more limiting under the experimental conditions. Infusion of the other essential amino acids increased $(P \leq 0.10)$ the arterial concentrations in respect to the pre-experimental period. Lysine, threonine, and valine showed lower increments than other essential amino acids. Among the nonessential amino acids, glutamate and alanine concentration showed a significant decrease $(P<0.05)$ during the abomasal and the jugular infusions compared with the pre-experimental period. Aspartate, glutamine, and tyrosine concentrations followed similar numerical trends.

The jugular infusion of amino acids, in respect to the pre-experimental period, increased $(P=0.02)$ total amino acid concentration in arterial plasma whereas the abomasal infusion did not increase it to a significant extent. Both infusion sites of the amino acid mixture increased $(P<0.01)$ the arterial concentration of the total essential amino acids in comparison to the pre-experimental period. In contrast, the arterial concentration of total nonessential amino acids tended to decrease $(P=0.10)$ with the abomasal infusion but not with the jugular infusion, in respect to the pre-experimental period (Tab. IV). Low essential:nonessential amino acid concentration ratios are characteristic of feeding inadequate amount of protein [8] and will increase when protein balance is improved $[8,18,26]$. This ratio increased $(P<0.01$; Tab. IV) in response to both abomasal and jugular infusions in the present experiment. It has been hypothesized that the increase in arterial concentration of nonessential amino acids when 
Table IV. Arterial concentrations of amino acids $(\mu \mathrm{M})$ occurring when either cows were fed $71 \%$ crude protein requirements during the pre-experimental period (pre-exp) or when they received either an abomasal (Abo) or jugular (Jug) infusion of fifteen amino acids (AA) ${ }^{1}$.

\begin{tabular}{|c|c|c|c|c|c|c|c|c|}
\hline & \multirow[b]{2}{*}{ pre-exp } & \multirow[b]{2}{*}{ SEM } & \multicolumn{3}{|c|}{ Infusion site } & \multicolumn{3}{|c|}{ Probability } \\
\hline & & & Abo & Jug & SEM & $\begin{array}{c}\text { site } \\
\text { effect }^{2}\end{array}$ & $\begin{array}{l}\text { pre-exp } \\
\text { vs. Abo }{ }^{3}\end{array}$ & $\begin{array}{l}\text { pre-exp } \\
\text { vs. Jug }\end{array}$ \\
\hline \multicolumn{9}{|c|}{ Essential AA (E) } \\
\hline Arg & 77.2 & 5.1 & 106.0 & 110.4 & 6.0 & ns & 0.03 & 0.04 \\
\hline His & 19.0 & 1.1 & 34.8 & 36.9 & 2.0 & $\mathrm{~ns}$ & $<0.01$ & 0.02 \\
\hline Ile & 125.4 & 4.1 & 167.6 & 193.2 & 7.2 & 0.07 & 0.03 & $<0.01$ \\
\hline Leu & 115.8 & 4.0 & 179.9 & 200.3 & 5.9 & 0.07 & $<0.01$ & $<0.01$ \\
\hline Lys & 83.6 & 3.2 & 103.5 & 117.7 & 5.1 & $\mathrm{~ns}$ & 0.03 & $<0.01$ \\
\hline Met & 12.1 & 4.1 & 13.6 & 13.9 & 0.2 & $\mathrm{~ns}$ & ns & ns \\
\hline Phe & 43.4 & 2.8 & 51.1 & 62.0 & 4.6 & ns & $<0.01$ & 0.05 \\
\hline Thr & 102.6 & 9.7 & 130.6 & 138.6 & 5.9 & $\mathrm{~ns}$ & 0.09 & 0.03 \\
\hline Val & 288.8 & 13.0 & 349.6 & 389.8 & 15.3 & ns & 0.07 & 0.02 \\
\hline Total E & 861 & 2 & 1136 & 1263 & 34 & 0.06 & $<0.01$ & $<0.01$ \\
\hline \multicolumn{9}{|c|}{ Nonessential AA (NE) } \\
\hline Ala & 272.2 & 8.5 & 244.7 & 264.5 & 6.9 & ns & 0.03 & ns \\
\hline Asp & 17.2 & 2.3 & 15.5 & 15.8 & 1.2 & ns & $\mathrm{ns}$ & $\mathrm{ns}$ \\
\hline Gln & 142.2 & 11.4 & 112.6 & 127.5 & 9.7 & $\mathrm{~ns}$ & $\mathrm{~ns}$ & $\mathrm{~ns}$ \\
\hline Glu & 184.7 & 11.2 & 162.0 & 153.7 & 10.1 & $\mathrm{~ns}$ & $\mathrm{~ns}$ & 0.01 \\
\hline Gly & 244.1 & 23.1 & 226.2 & 272.5 & 28.4 & $\mathrm{~ns}$ & $\mathrm{~ns}$ & $\mathrm{~ns}$ \\
\hline Ser & 95.3 & 3.2 & 97.5 & 106.4 & 4.5 & ns & $\mathrm{ns}$ & $\mathrm{ns}$ \\
\hline Tyr & 47.7 & 3.7 & 41.5 & 44.8 & 2.4 & ns & $\mathrm{ns}$ & $\mathrm{ns}$ \\
\hline Total NE & 986 & 5 & 901 & 985 & 46 & ns & 0.10 & $\mathrm{~ns}$ \\
\hline $\mathrm{E}+\mathrm{NE}$ & 1847 & 64 & 2037 & 2248 & 77 & $\mathrm{~ns}$ & $\mathrm{~ns}$ & 0.02 \\
\hline Ratio E/NE & 0.88 & 0.03 & 1.30 & 1.30 & 0.03 & $\mathrm{~ns}$ & $<0.01$ & $<0.01$ \\
\hline
\end{tabular}

${ }^{1}$ Least square means with pooled standard error of the mean (SEM) are presented in the table.

${ }^{2}$ Probability of infusion site effect (Abo vs. Jug).

${ }^{3}$ Probability of the paired t-test comparison (see materials and methods) between the basal diet (pre-exp) and each infusion sites (Abo and Jug); ns = non significant, $P>0.10$.

protein intake is low, allows the animal to compensate for the decline in essential amino acid concentrations, by conserving the $\alpha$-amino $\mathrm{N}$ group within the body [20]. Overall, according to the current results, animals were in a protein deficiency during the pre-experimental period and their $\mathrm{N}$ status was improved by infusions.

The summation of arterial concentration of essential amino acids tended to increase
$(P=0.06$; Tab. IV) with the jugular infusion, in respect to the abomasal infusion, with leucine and isoleucine increment reaching a tendency $(P=0.07)$. Therefore, the first-pass through the splanchnic tissues of essential amino acids infused into the abomasum caused a $11 \%$ decrease in their arterial concentration relative to the jugular infusion. The total arterial concentration of essential amino acids would be more sensitive than milk protein output to assess the 
effect of liver metabolism on peripheral delivery of amino acids. The magnitude of the impact of splanchnic metabolism would then be in accordance with the hepatic removal of essential amino acids relative to their total hepatic supply rather than relative to new input into the body as absorbed amino acids.

\subsection{Glucose metabolism}

Arterial glucose concentrations were greater (3.09 to $3.42 \mathrm{mM}$; $\mathrm{SEM}=0.08$; $P=0.04$ ) during the jugular infusion, but arterial insulin concentration was unaltered (0.607 ng. $\mathrm{mL}^{-1}$; SEM 0.084). This increase in glucose availability may relate to the $0.8 \mathrm{~kg}$ extra milk production occurring with the jugular infusion. Infusion of amino acids into the abomasum involved their transit across the intestinal tissues which extensively utilize nonessential amino acids in lactating cows [9], thus decreasing their delivery to the liver. In consequence, the abomasal infusion would reduce the amounts available for gluconeogenesis in the view of the fact that non-essential amino acids are important precursors of glucose in ruminants [10, 47]. Unaltered milk yield and glucose concentration following abomasal or duodenal infusions of amino acids or casein in cows well fed in protein have been reported [19, 32, 42]. All together with the current results, this suggests that gluconeogenesis from non-essential amino acids may be stimulated by amino acid infusions when cows are fed below their protein requirements.

\subsection{Mammary metabolism}

Infusion sites had no effect on arteriovenous concentration difference as well as on the extraction rate for either glucose or amino acids across the mammary gland (data not presented). Calculated mammary plasma flow was not affected by infusion sites, and net fluxes of amino acids and glucose were similar between treatments (Tab. V). Simi- larly, the infusion sites did not modify the efficiency of utilization of essential amino acids for milk protein synthesis (uptake to output ratio; Tab. V). The amounts of methionine and histidine extracted from plasma were less than secreted in milk. Therefore, alternative sources for these two amino acids must be involved, e.g. delivery from red blood cells $[33,45]$ or from peptide breakdown. The putative contribution from peptides to milk phenylalanine and tyrosine has been shown to increase as the arterial supply of the free amino acids decreased in lactating goats [5]. In the current study, therefore, the peptide contribution to milk methionine and histidine may be a consequence of their low arterial concentrations as a free source. Similarly, the mammary net uptake of phenylalanine and tyrosine could have partially been provided by plasma peptides. However, this occurrence appears less likely in the current study given that the variation in the arterial concentration of phenylalanine does not exhibit a limiting amino acid pattern as observed for methionine and histidine. A similar argument cannot be made for tyrosine given that the arterial concentrations of most non-essential amino acids were not altered by infusions. However, in the circumstance that milk phenylalanine and tyrosine would have been partially provided by peptides, therefore the mammary plasma flow would be overestimated.

The present results also show that the arterial limitation in methionine did not affect mammary blood flow as observed when histidine severely limited milk protein synthesis [6]. Such mammary arterial blood flow adjustment has also been observed when methionine was limiting milk protein synthesis [22]. Comparison between experiments suggests that the udder adjusts blood flow according to the extent of the arterial limitation, requiring mammary arterial blood flow adjustment with severe histidine limitation [6] and adapting to less severe limitation in histidine by increasing mammary extraction rate [25]. 
Table V. Mammary plasma flow $\left(\mathrm{L} \cdot \mathrm{h}^{-1}\right)$, net flux $\left(\mathrm{mmol} \cdot \mathrm{h}^{-1}\right)$ and uptake to output ratio of amino acids and glucose in cows receiving an abomasal (Abo) or jugular (Jug) infusion of fifteen amino acids ${ }^{1}$.

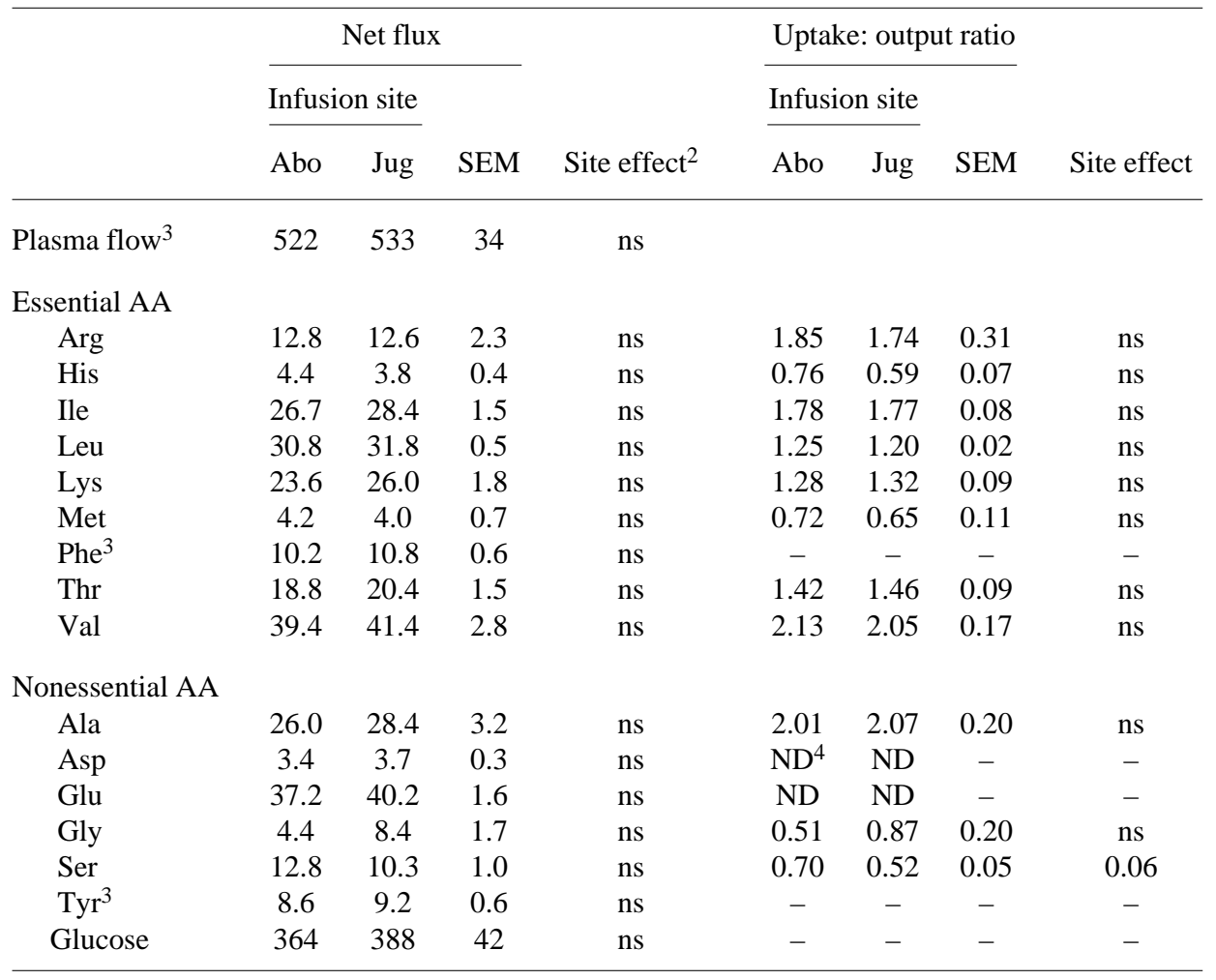

${ }^{1}$ Least square mean with pooled standard error of the mean (SEM) of each parameter is presented for the whole mammary gland.

${ }^{2}$ Probability of infusion site effect (Abo vs. Jug); ns = non significant, $P>0.10$.

${ }^{3}$ Plasma flow was estimated with Fick principle using phenylalanine and tyrosine. Uptake to output ratio was therefore not calculated for these two amino acids.

${ }^{4} \mathrm{ND}=$ not determined in milk (see materials and methods).

\section{CONCLUSIONS}

The influence of splanchnic metabolism on milk protein secretion was investigated by comparing the response of lactating cows to an amino acid mixture infused into the abomasum or a jugular vein. Milk crude protein content and yield were similar for both infusion sites. The increment of arterial plasma glucose during the jugular infusion would likely explain the modest increase in milk yield and could be related to increased availability of non essential amino acids when intestinal metabolism is first bypassed. The jugular infusion of amino acids increased arterial concentration of total essential amino acids by $11 \%$ in comparison to the abomasal infusion, suggesting an impact of liver metabolism on peripheral delivery of amino acids in the magnitude of the ratio of liver removal relative to total influx rather than relative to portal absorption. Therefore, recirculation of amino acids would reduce the importance of first-pass splanchnic metabolism of amino acids at least in terms of the mammary arterial 
supply of amino acids. Mammary plasma flow and amino acid net fluxes were not altered by treatments, suggesting that the mammary metabolism remained unaffected by this range of change in arterial supply.

\section{ACKNOWLEDGMENTS}

Special appreciations are extended to Degussa Hüls for providing amino acids. Acknowledgements are extended to Lysa Croteau for her technical assistance and to André Roy for his expertise in amino acid analyses. This work was supported by a grant from the Natural Sciences and Engineering Research Council of Canada. M.C. Thivierge is the recipient of a scholarship granted by the Natural Sciences and Engineering Research Council of Canada.

\section{REFERENCES}

[1] Aikman P.C., Reynolds C.K., Lupoli B., Humphries D.J., Sutton J.D., France J., Beever D.E., MacRae J.C., Milk protein response to abomasal and mesenteric vein infusions of essential amino acids in dairy cows fed low protein concentrates, J. Anim. Sci. 77 Suppl. 1 (1999) 266.

[2] Arambel M.J., Bamiley E.E., Dufva G.S., Nagaraja T.G., Dayton A.D., Effect of diet on amino and nucleic acids of rumen bacteria and protozoa, J. Dairy Sci. 65 (1982) 2095-2101.

[3] Association of Official Analytical Chemists, Official Methods of Analysis, 15th ed., Arlington, VA, 1990.

[4] Bach A., Huntington G.B., Stern M.D., Response of nitrogen metabolism in preparturient dairy cows to methionine supplementation, J. Anim. Sci. 78 (2000) 742-749.

[5] Bequette B.J., Backwell F.R.C., Kyle C.E., Calder A.G., Buchan V., Crompton L.A., France J., MacRae J.C., Vascular source of phenylalanine, tyrosine, lysine, and methionine for casein synthesis in lactating goats, J. Dairy Sci. 82 (1999) 362-377.

[6] Bequette B.J., Hanigan M.D., Calder A.G., Reynolds C.K., Lobley G.E., MacRae J.C., Amino acid exchange by the mammary gland of lactating goats when histidine limits milk production, J. Dairy Sci. 83 (2000) 765-775.

[7] Bergen W.G., Free amino acids in blood of ruminants-physiological and nutritional regulation, J. Anim. Sci. 49 (1979) 1577-1589.

[8] Bergen W.G., Henneman H.A., Magee W.T., Effect of dietary protein level and protein source on plasma and tissue free amino acids in growing sheep, J. Nutr. 103 (1973) 575-585.
[9] Berthiaume R., Dubreuil P., Stevenson M., McBride B.W., Lapierre H., Intestinal disappearance and portal appearance of amino acids in dairy cows fed ruminally protected methionine, J. Dairy Sci. 84 (2001) 194-203.

[10] Black A.L., Anand R.S., Bruss M.L., Brown C.A., Nakagiri J.A., Partitioning of amino acids in lactating cows: oxidation to carbon dioxyde, J. Nutr. 120 (1990) 700-710.

[11] Canadian Council on Animal Care, Guide to care and used of experimental animals, Vol. 1, 2nd ed., Bradda Printing Services, Inc., Ottawa, ON, 1993.

[12] Cant J.P., DePeters E.J., Baldwin R.L, Mammary amino acid utilization in dairy cows fed fat and its relationship to milk protein synthesis, J. Dairy Sci. 76 (1993) 762-774.

[13] Cecava M.J., Merchen N.R., Berger L.L., Fahey G.C. Jr., Effects of dietary energy level and protein source on site of digestion and duodenal nitrogen and amino acid flows in steers, J. Anim. Sci. 66 (1988) 961-974.

[14] Chamberlain D.G., Thomas P.C., Ruminal nitrogen metabolism and the passage of amino acids to the duodenum in sheep receiving diets containing hay and concentrates in various proportions, J. Sci. Food Agric. 30 (1979) 677-686.

[15] Crompton L.A., Reynolds C.K., Lomax M.A., Bequette B.J., Backwell F.R.C., Sutton J.D., MacRae J.C., Beever D.E., Effect of duodenal essential amino acid infusions on milk yield and composition in lactating dairy cows, Proc. Nutr. Soc. 56 (1997) 172A.

[16] Czerkawski J.W., Chemical composition of microbial matter in the rumen, J. Sci. Food Agric. 27 (1976) 621-632.

[17] Dinn N.E., Shelford J.A., Fisher L.J., Use of the cornell net carbohydrate and protein system and rumen-protected lysine and methionine to reduce nitrogen excretion from lactating dairy cows, $\mathrm{J}$. Dairy Sci. 81 (1998) 229-237.

[18] Foldager J., Hubert J.T., Bergen W.G., Factors affecting amino acids in blood of dairy cows, J. Dairy Sci. 63 (1980) 396-404.

[19] Fraser D.L., Orskov E.R., Whitelaw F.G., Franklin M.F., Limiting amino acids in dairy cows given casein as the sole source of protein, Livest. Prod. Sci. 28 (1991) 235-252.

[20] Grimble R.F., Whitehead R.G., Changes in the concentration of specific amino acids in the serum of experimentally malnourished pigs, Brit. J. Nutr. 24 (1970) 557-564.

[21] Guinard J., Rulquin H., Effect of graded levels of duodenal infusions of casein on mammary uptake in lactating cows. 2. Individual amino acids, J. Dairy Sci. 77 (1994) 3304-3315.

[22] Guinard J., Rulquin H., Effects of graded amounts of duodenal infusions of methionine on the mammary uptake of major milk precursors in dairy cows, J. Dairy Sci. 78 (1995) 2196-2207. 
[23] Huntington G.B., Net absorption of glucose and nitrogenous compounds by lactating Holstein cows, J. Dairy Sci. 67 (1984) 1919-1927.

[24] Jensen R.G., Handbook of milk composition, Academic Press inc., London, UK, 1995.

[25] Korhonen M., Vanhatalo A., Varvikko T., Huhtanen P., Responses to graded postruminal doses of histidine in dairy cows fed grass silage diets, J. Dairy Sci. 83 (2000) 2596-2608.

[26] Kung L., Huber J.T., Bergen W.G., Petitclerc D., Amino acids in plasma and duodenal digesta and plasma growth hormone in cows fed varying amounts of protein of differing degradability, J. Dairy Sci. 67 (1984) 2519-2524.

[27] Lallès J.P., Poncet C., Toullec R., Composition en acides aminés des bactéries libres et des bactéries fixées aux particules alimentaires du réticulo-rumen du veau sevré et du mouton recevant différentes rations, Ann. Zootech. 41 (1992) 75-76

[28] Lapierre H., Farmer C., Girard C., Brazeau P., Effect of age and intake on growth hormone kinetics in dairy heifers, Dom. Anim. Endocrinol. 9 (1992) 199-207.

[29] Lapierre H., Bernier J.F., Dubreuil P., Reynolds C.K., Farmer C., Ouellet D.R., Lobley G.E., The effect of feed intake level on splanchnic metabolism in growing beef steers, J. Anim. Sci. 78 (2000) 1084-1099.

[30] Lobley G.E., Lapierre H., Nitrogen (N): from mouth to milk in: Southwest Nutrition and Management Conference Proceedings, University of Arizona, Phoenix, Arizona, 2001, pp. 81-99.

[31] Lobley G.E., Milano G.D., Van Der Walt J.G., The liver: Integrator of nitrogen metabolism, in: Proceedings of the IX International Symposium on Ruminant Physiology, Pretoria, South Africa, 1999.

[32] Mackle T.R., Dwyer D.A., Bauman D.E., Effects of branched-chain amino acids and sodium caseinate on milk protein concentration and yield from dairy cows, J. Dairy Sci. 82 (1999) 161-171.

[33] Mackle T.R., Dwyer D.A., Ingvartsen K.L., Chouinard P.Y., Ross D.A., Bauman D.E., Evaluation of whole blood and plasma in the interorgan supply of free amino acids for the mammary gland of lactating dairy cows, J. Dairy Sci. 83 (2000) 1300-1309.

[34] MacRae J.C., Bequette B.J., Crompton L.A., Synthesis of milk protein and opportunities for nutritional manipulation in: Milk composition, BSAS Occasional Publication No. 25, 2000, pp. 179-199.

[35] Martin C., Bernard L., Michalet-Doreau B., Influence of sampling time and diet on amino acid composition of protozoal and bacterial fractions from bovine ruminal contents, J. Anim. Sci. 74 (1996) 1157-1163.
[36] Mepham T.B., Amino acid utilization by the mammary gland, J. Dairy Sci. 65 (1982) 287-298.

[37] Metcalf J.A., Crompton L.A., Backwell F.R.C., Bequette B.J., Lomax M.A., Sutton J.D., MacRae J.C., Beever D.E., The response of dairy cows to intravascular administration of two mixtures of amino acids, Anim. Sci. 62 (1996) 643-644.

[38] Metcalf J.A., Wray-Cahen D., Chettle E.E., Sutton J.D., Beever D.E., Crompton L.A., MacRae J.C., Bequette B.J., Backwell F.R.C., The effect of increasing levels of dietary crude protein as protected soya on mammary metabolism in lactating dairy cows, J. Dairy Sci. 79 (1996) 603-611.

[39] Metcalf J.A., Wray-Cahen D., Crompton L.A., Lomax M.A., Bequette B.J., MacRae J.C., Backwell F.R.C., Lobley G.E., Sutton J.D., Beever D.E., Responses in milk copstituents to intravascular administration of two mixtures of amino acids in dairy cows, J. Dairy Sci. 79 (1996) 1425-1429.

[40] National Research Council, Nutrient Requirements of Dairy Cattle, Version 6th ed., Natl. Acad. Sci., Washington, DC, 1989.

[41] SAS ${ }^{\circledR}$ User's Guide: Statistics, Version 5 Edition, SAS Inst., Inc. Cary, NC, 1985.

[42] Schwab C.G., Satter L.D., Clay A.B., Response of lactating dairy cows to abomasal infusion of amino acids, J. Dairy Sci. 59 (1976) 1254-1270.

[43] Strumia M.M., Sample A.B., Hart E.D., An improved micro hematocrit method, Am. J. Clin. Path. 24 (1954) 1016-1024.

[44] Thivierge M.C., Petitclerc D., Bernier J.F., Couture Y., Lapierre H., External Pudic Venous Reflux into the Mammary Vein in Lactating Dairy Cows, J. Dairy Sci. 83 (2000) 2230-2238.

[45] Thivierge M.C., Petitclerc D., Bernier J.F., Couture Y., Lapierre H., Variations of Mammary Metabolism as the Udder Gradually Fills with Milk during a 12-h period following Milking, J. Dairy Sci. (in press).

[46] Van Soest P.G., Robertson J.B., Analysis of Forages and Fibrous Foods, Cornell Univ. Press, Ithaca, NY, 1985.

[47] Wolff J.E., Bergman E.N., Gluconeogenesis from plasma amino acids in fed sheep, Am. J. Physiol. 223 (1972) 455-460.

[48] Wray-Cahen D., Metcalf J.A., Backwell F.R.C., Bequette B.J., Brown D.S., Sutton J.D., Lobley G.E., Hepatic response to increased exogenous supply of plasma amino acids by infusion into the mesenteric vein of Holstein-Friesian cows in late gestation, Br. J. Nutr. 78 (1997) 913-930.

[49] Wright T.C., Moscardini S., Luimis P.H., Susmel P., McBride B.W., Effects of rumen-undegradable protein and feed intake on nitrogen balance and milk protein production in dairy cows, J. Dairy Sci. 81 (1998) 784-793. 